J O U R A L O F

French and Francophone Philosophy
REVUE DE LA

philosophie française et de langue française

\title{
Absurd Dignity: The Rebel and His Cause in Améry and Camus
}

Ingrid L. Anderson

Journal of French and Francophone Philosophy - Revue de la philosophie française et de langue française, Vol XXIV, No 3 (2016) 74-94.

\author{
Vol XXIV, No 3 (2016) \\ ISSN 1936-6280 (print) \\ ISSN 2155-1162 (online) \\ DOI 10.5195/ jffp. 2016. 788 \\ www.jffp.org
}

\section{(c) EY-NC-ND}

This work is licensed under a Creative Commons Attribution-Noncommercial-No Derivative Works 3.0 United States License.

\section{ULIS D-Sunt}

This journal is operated by the University Library System of the University of Pittsburgh as part of its D-Scribe Digital Publishing Program, and is co-sponsored by the University of Pittsburgh Press 


\title{
Absurd Dignity
}

\section{The Rebel and His Cause in Améry and Camus}

\author{
Ingrid L. Anderson \\ Boston University
}

I must confess I don't know exactly what [human dignity] is...I don't know if the person who is beaten by the police loses human dignity. Yet I am certain that with the very first blow that descends on him he loses something we will perhaps temporarily call 'trust in the world'...with the first blow from the policeman's fist, against which there can be no defense and which no helping hand will ward off, a part of our life ends and it can never again be revived. ${ }^{1}$

In "On the Necessity and Impossibility of Being a Jew," Jean Améry admits that in Europe, "the degradation of the Jews was...identical with the death threat long before Auschwitz. In this regard, Jean-Paul Sartre, already in...his book Anti-Semite and Jew, offered a few perceptions that are still valid today." 2 In no uncertain terms, Améry aligns his own project to "describe the...unchanging...condition" of the Reich's victims with Sartre's 1946 book on anti-Semitism, a philosophical gesture that was not uncommon for leftleaning Jewish intellectuals after the war. According to Robert Misrahi, who discusses at length what he calls Sartre's "evident good will," "his manifest care to render justice, and his desire, in the face of the Jews' great suffering, to address himself to them," Anti-Semite and Jew was primarily a "powerful affirmation of sympathy" for European Jews and, moreover, "an effective weapon against anti-Semitism." 3 Misrahi insists that French Jews were "astonished, even stunned for what we (Jews) were used to was hatred and contempt." 4 Sartre's repeated assertions that the suffering of European Jewry was undeserved and unwarranted, are underscored by his declaration that Europe's problem was not, after all, 'the Jew' but the anti-Semite, whose sadistic Manichaeism ${ }^{5}$ and profound fear of himself and his own instincts and responsibilities, ${ }^{6}$ had inverted European values so profoundly as to make genocide ethical. And although Sartre repeatedly emphasizes his intention to analyze primarily the situation of French Jews, he does not fail 
to connect European anti-Semitism with other forms of racialized hatred; 'the Jew' is only a "pretext," since "elsewhere [the anti-Semite's] counterpart will make use of the Negro or the man of yellow skin" because antiSemitism, "in short, is fear of the human condition." 7 Given the profound radicalism of such declarations at the time, it is not a surprise that Améry confessed and enacted a deep affinity for Sartrean existentialism. And yet, despite Améry's understandable eagerness to wave the Sartrean flag, Améry's existentialism is less like Sartre's, and, consciously or unconsciously, far more like that of Albert Camus. Although Améry never mentions Camus in At the Mind's Limits, Améry shares Camus' reverence for rigorous analysis that simultaneously resists the kind of moral and political rigidity that often leads to a falsification of human experience and history. This is perhaps most evident in their overlapping treatments and understandings of human dignity and its solitary champion, the absurdist 'rebel.'

In Améry's preface to the 1977 reissue of At the Minds Limits, he asserts that, given the "horror" of the latter half of the twentieth century, a revised edition" of the original collection of essays "would be nothing but a trick, a journalistic tribute to actuality." He is "unwilling to retract anything...said" in the first addition from 1966, and that he has "little to add to it." 8 Améry remarks that, after the fall of the Reich, the twentieth century appears to have produced more of the same, but Améry does not actually equate the crimes of the Third Reich with those committed by subsequent regimes, regimes that he agrees are also responsible for "invasions, aggressions, torture, [and] the destruction of man in his essence." 9 For Améry, despite the qualitative similarities between regimes that specialize in what Primo Levi called the "demolition of a man," the philosophical nihilism and wholehearted brutality of the Reich are utterly and unmistakably distinct. That a nation of "Poets and Thinkers" became a people who "placed torture in their service...[and] even more fervently...were its servants" 10 is for Améry inexplicable.

The assumption that the Third Reich is historically unique is not unusual among Jewish intellectual responses to the profound destruction of World War II. Richard Rubenstein, Emil Fackenheim, Irving Greenberg, Steven T. Katz, and many others have insisted-and often for different reasons - that the Holocaust is a unique event in human history. And yet it is not as a religious or "cultural" Jew that Améry himself makes this assertion, but as a philosopher forced to accept the legally binding role of 'Jew' in mid-twentieth century Europe. It is therefore as this kind of a 'Jew' that Améry approaches the problem of "radical Evil" and the Holocaust. First and foremost, Améry experiences the unsparing brutality of Nazi Germany as a self-defined humanist, intellectual, and rebel. "This Evil" that overtook mid-twentieth century Germany, he writes, "really is singular and irreducible in its total inner logic and its accursed rationality."11 But Améry 
also strongly suggests that "Hitler has gained a posthumous triumph."12 This triumph is arguably not best evidenced by the resurgence of Nazism in Europe, or even post 1945 recurrences of genocide in Europe and elsewhere.

Instead, it is the legacy of the Enlightenment that Améry fears the Third Reich and its offspring may have irretrievably mangled. For Améry, the "concept of enlightenment must not be too restricted methodologically, for...it embraces more than logical deduction and empirical verification." Rather, it is "the will and the ability to speculate phenomenologically, to empathize, to approach the limits of reason." 13 This harmonization of empathy and reason prevents doctrinal commitments and philosophical methodologies from limiting or even obliterating our innate empathy for our fellow man as our fellow and neighbor. "Only when we fulfill the law of enlightenment," Améry muses, "and at the same time transcend it do we reach intellectual realms in which ratio does not lead to shallow rationalism." 14 Empathy is the ultimate enemy and first victim of this cold and shallow rationalism; nurtured by "restricted methodology" and enabled by what Améry bitingly terms "unchecked self-expansion," the phenomenon that Emmanuel Levinas called "Hitlerism" reappears only somewhat transformed around the globe under different names and in different locations, led by slightly different men masquerading as demigods. Like the epidemic that cripples Oran, the town beset with the Black Death in Camus' 1946 novel, The Plague, these regimes are virulent strains of the Nazi original, and, for Améry and Camus, they are as much products of the Enlightenment as democracy. What makes these plagues deadly is their form as much as their content; societies susceptible to these "illnesses" are constituted by populations unwilling to think too much, to do the work of bringing empathy into concert with the rational mind, to allow one faculty to limit and enhance the other. Such societies do not want to transcend systems; they want to adopt them. For Améry, this occurs with increasing ease and is perhaps Hitler's most devastating legacy.

By 1951 when The Rebel was first published in France, Camus' absurdism was already familiar to his readers. The Myth of Sisyphus appeared nearly ten years earlier in 1941, and is, along with The Stranger, considered the beginning of Camus' formation of his own brand of absurdism. Camus begins his 1951 treatise by defining absurdism as a viable political and philosophical approach to rebellion; but The Rebel is first and foremost an exploration and condemnation of the ubiquity of nihilism in the most powerful revolutionary doctrines of his time. The mightiest tool in Camus' arsenal is his carefully parsed analysis of "the rebel," who at his best is not one of the same among many, but an individual, who feels his suffering has exceeded his endurance; the absurdist rebel's validation of his own worth is in fact a validation of the worth of all men, and an implicit rejection of murder, and by extension, suicide. Camus, an ardent leftist, insisted that true loyalty to communism required supporters to justify the 
murder of innocents when committed for the sake of an imminent-butalways-deferred global revolution. Camus argues convincingly that the revolutionary desire for a perfected, inevitable future, when coupled with ethical and philosophical bankruptcy, not only rationalizes the suspension of morality, but also ultimately necessitates it. The rejection of what is eventually requires the elaboration of what ought to be-an admirable and definitive urge, which is native to human nature, and yet easily lead off course. Camus writes,

....as soon as a man takes refuge in doctrine, as soon as crime reasons about itself, it multiplies like reason itself and assumes all the aspects of syllogism. Once crime was as solitary as a cry of protest; now it is as universal as science. Yesterday it was put on trial; today, it determines the law. ${ }^{15}$

Améry, too, identifies murderous nihilism as the defining trait of the most brutal twentieth century regimes. This nihilism is carnivorous and cannibalistic at the same time that it is idealist. While Améry observes that torture is the "essence" of the Reich, a regime unique in its original formation, the use of torture as the ultimate colonizer did not disappear from human politics and culture at Germany's final collapse, but flourished:

A world in which torture, destruction, and death triumph obviously cannot exist. But the [existential sadist] does not care about the continued existence of the world. On the contrary: he wants to nullify the world, by negating his fellow man, who also in an entirely specific sense is "hell" for him, he wants to recognize his own total sovereignty...the radical negation of the other, as the denial of the social principle and the reality principle... ${ }^{16}$

Here, Améry identifies the desire for radical annihilation as a product of a regrettably rigid form of human rebellion; Camus and Améry describe the enactment of this revolutionary nihilism in strikingly similar terms. Améry insists that his torturers knew that they had "expanded into the bodies of [their] fellow man and extinguished what was his spirit..."17 "With heart and soul," Améry mourns,

they went about their business, and the name of it was power, dominion over spirit and flesh, orgy of unchecked selfexpansion...there were moments when I felt a kind of admiration for the agonizing sovereignty they exercised over me. For is not the one who can reduce a person so entirely to a body and a whimpering prey of death a god, or at least a demigod?18

The relation between the torturer and the tortured is primal and human, defined in large part by the struggle for sovereignty over self and other. In Camus' analyses of "Romantic" and "Dandyist" rebels, he suggests that in the late nineteenth and early twentieth centuries, the human spirit of 
rebellion falls victim to "extreme consequences of logic...an aristocracy of cynicism, and a desire for an apocalypse." 19 According to Camus, Romantic rebellion emphasizes the "powers of defiance and refusal...and forgets its positive content." 20 The result is a rejection of salvation itself, a phenomenon Camus explores most powerfully in his explication of Ivan from The Brothers Karamozov.

For Ivan the Romantic rebel, justice ranks above divinity; God is refuted in the name of morality, and denied on the principle of love for humanity. Ivan subsequently abandons any correlation between "suffering and truth." In an arguably logical but chilling deduction, Ivan finally concludes that "there is no possible salvation for a man of compassion...One step more," Camus observes, "and from All or Nothing we arrive at Everyone or No One." 21 Thus Améry's torturer wants to "nullify the world" by destroying his fellow man. What begins as man's just "rebellion against his condition... and enlists the individual in the defense of a dignity common to all men" 22 can forget itself, forget the origin of the revolt to which man has committed. In the best moments of his rebellion, the rebel indeed asserts "this far and no more" with regard to the conditions in which he lives at the same time that he shouts yes from the rooftops to the dignity of every man. Camus writes,

In order to exist, man must rebel, but rebellion itself must respect the limit it discovers in itself - a limit where minds meet and, in meeting, begin to exist...In absurdist experience, suffering is individual. But from the moment when a rebellion begins, suffering is... a collective experience...human reality, in its entirety, suffers from the distance which separates it from the rest of the universe...In our daily trials, rebellion...is the first piece of evidence...It founds its first value on the whole human race. I rebel - therefore I exist. ${ }^{23}$

When the rebel's "categorical rejection of an intrusion that is considered intolerable" loses "conviction [in its] absolute right," 24 a value to which he must say yes, then the rebel becomes set on negation, a state of mind that justifies the destruction of the human solidarity in which rebellion is grounded. "We have then, the right to say," Camus insists, "that any rebellion which claims the right to deny or destroy this solidarity loses simultaneously its right to be called rebellion and becomes in reality an acquiescence in murder." 25

This rejection of murder so clearly stated in Camus' corpus includes the rejection of capital punishment, an institution Camus abhorred. In the years immediately following WWII, Camus was among the few public left wing figures to vehemently oppose capital punishment for French fascists and Nazi sympathizers, despite his disgust for fascism; his almost visceral reasons for categorically rejecting capital punishment in any and all 
circumstances - a point of view Sartre denounced and found politically suspect-are perhaps best outlined in The Rebel. Again, Camus argues that "revolt is an essential dimension" of mankind that can be understood in absurdist terms: "...absurdist analysis, in its most important deduction, finally condemns murder. The final conclusion of absurdist reasoning is...the repudiation of suicide and the acceptance of the desperate encounter between human inquiry and the silence of the universe." 26 Absurdism is an "experience to be lived through, a point of departure" 27 that nonetheless insists upon living life, an act that is itself a value judgment. ${ }^{28}$ For Camus, rebellion itself constitutes both a declaration that "human life is the only good" as well as a rejection of chaos in favor of unity and order. He writes:

Rebellion cannot exist without the feeling that somewhere and somehow, one is right...[the rebel] demonstrates, with obstinacy, that there is something in him which "is worth while..." and which must be taken into consideration...he confronts an order of things which oppresses him [while insisting on the] right not to be oppressed beyond the limit that he can tolerate. ${ }^{29}$

Camus' rejection of the death penalty was not born of pacifism, although Camus had once identified with French pacifism. Near the end of war when Camus was most active in the Resistance, he wrote in Lettres à un ami allemand that he "had accepted the sword now" and that "We have had to overcome our liking for man and the image that we created of a peaceful destiny...We needed to make a long detour and are very late." 30

Camus' rejection of capital punishment under any and all circumstances marks the beginning of the parting of the ways between himself and Sartre. In 1945, less than a year after the liberation of Paris, known collaborator and writer Robert Brassilach was sentenced to death. A number of intellectuals signed a petition requesting that de Gaulle pardon Brasillach; among those who signed the petition, only two (François Mauriac and Jean Paulhan) were noted Resistance activists like Camus. Novelist Marcel Aymé wrote to Camus requesting his support for the petition, which Camus granted, but not without anguish. In a letter to Aymé, he wrote:

I have always been horrified by death sentences and I decided...that I could not participate in one, even by abstraction...it is a scruple which I imagine will make Brasillach's friends laugh a lot. And [if] Brasillach...is pardoned...I want this letter to tell him the following, from me: I did not add my signature to yours for his sake, nor for the writer, whom I consider as nothing at all, nor for the person, whom I despise with all the force that is in me. ${ }^{31}$

Sartre, Simone de Beauvoir, and others refused to sign Brasillach's petition. Beauvoir insisted that if she did anything at all to help a man like Brasillach, who openly supported murder and genocide, "she would deserve to have her friends "spit in her face."" Brasillach had collaborated directly with the 
Gestapo, and could not be spared. In the end, Brasillach was shot at the Fresnes Prison on February 3. ${ }^{32}$

The difference in opinion regarding the proper response to Brasillach's crimes is indicative of the fundamental political and philosophical divergence that grew more distinct after 1945 between Sartre and Camus and the streams of leftist thought they represent. Camus' biographer, Olivier Todd speculates that Sartre's support and increasing appetite for violence was "Manichean," in part because Sartre was "not much involved with the Resistance, and his hardness toward the intellectual collaborators was inversely proportional to the risks he had run, while Camus, who had been more engaged, was less inflexible." 33 And unlike Sartre, Camus did not accept historical materialism, which he saw as the negation of freedom. In his Carnets, Camus mused, "By what right can a Communist or a Christian...reproach me for being a pessimist?" As he wrote in a letter to a Belgian divinity student in late 1945, "I have too much taste for life and a feeling for the world to believe that all is nothingness...I do not believe that negation encompasses everything, I only believe that it is the beginning of everything." 34 Even in 1938, when Camus reviewed Sartre's Nausea for Alger Republicain, he was unconvinced by Sartre's brand of existentialism, although he thought Sartre was brilliant. Regarding Sartre's hero, Roquentin, Camus claimed that, "the error of a certain literature is to believe that life is tragic because it is miserable...To observe that life is absurd is not an end, but a beginning." 35 The absurdist rebel sees this beginning as promising, an engaging yes rather than a rigid and theory-driven no.

Although a more in depth analysis of Améry's entanglement with Sartre's work is called for than can be delivered here, At the Mind's Limits and its deep-seated but often subdued riposte to Sartre's Anti-Semite and Jew suggests a similar rejection of doctrinal rigidity and a prioritization of theories that are often unsupported by human realities. Regarding AntiSemite and Jew, Misrahi asserts that Sartre's perceived "negation of all [Jewish] particularity and the affirmation of their egality vis a vis all men...inspired Jewish respect for Sartre." 36 One can imagine Améry among this number. Améry writes:

I see myself as a boy at Christmas, plodding through a snowcovered village to midnight mass; I don't see myself in a synagogue...The picture of my father...did not show me a bearded Jewish sage, but rather a Tyrolean Imperial Rifleman in the uniform of the First World War. I was nineteen years old when I heard of the existence of the Yiddish language, although...I knew...that my...very mixed family was regarded by the neighbors as Jewish... ${ }^{37}$

Améry did not hold dear, or even relate to, the markers of Jewishness to which Sartre so glibly refers in Anti-Semite and Jew. Sartre certainly speaks to 
experiences like Améry's when he acknowledges that, for many, the word "Jew" is not known to them in any positive sense until it is imposed on them with hostility; but he simultaneously utilizes essentializing language to describe Jews and their responses to the conditions they face in twentieth century Europe. The following passage, although perhaps soothing balm to the victims of genocide in that it does not defame them, nonetheless idealizes Jews and ignores the fact that these traits cannot possibly be applied to all Jews:

The Jews are the mildest of men, passionately hostile to violence. That sweetness which they conserve even in the midst of the most atrocious persecution, that sense of justice and of reason which they put up as their sole defense against a hostile, brutal and unjust society is perhaps the best part of the message they bring to us and is the true mark of their greatness. ${ }^{38}$

Here "the Jews" are not really human because they remain passive, even sweet, in the face of atrocities they suffer. Well-intended passages like these prompt Misrahi to assert that this doctrine of negation for which Sartre was so often lauded "does not exist in Sartre's book." Rather, Misrahi insists, Sartre "criticized the synthesis but not the affirmation of the Jews" "specific traits."'39 Misrahi is correct. Sartre attributes many traits to Jews: reflective behavior, rationalism, denial of the body, lack of tact, a special relation to money, basic doubling of sensibility, and "non-metaphysical quietude." Sartre presents these traits as "scattered" phenomenological data that is ultimately the "work of the Jew himself." For Sartre, the anti-Semite's mistake is to attribute these 'real' traits to every Jew on account of race. ${ }^{40}$ Misrahi's exact formulation is worth recounting here:

....according to Sartre, the scattered traits, which were very real in Jews...certainly did not have a biological origin, but even so they constituted a specific Jewish personality. How was this possible and how was this analysis presented as phenomenologically developed? It appeared that Sartre, in attempting to describe the psychological genesis of the Jewish being, had taken verity in what anti-Semites had said about Jews. ${ }^{41}$

Misrahi argues that, for Sartre, the "inauthentic Jew" confers Jewish traits upon himself, while the "authentic" Jew has no specific traits and chooses between being a French national without Jewish characteristics, or a Zionist in Palestine. Moreover,

In refusing to define himself by the others' reference, he became the negation of what the [anti-Semite] affirmed in him. The inauthenticity was thus the source of his Jewish character; but this source, even though it may have been the attitude of the Jew himself, was an alienated source because it was through the other (said 
Sartre) and not through himself that the Jew amassed, one by one, the traits that characterized him. ${ }^{42}$

This, then, is Sartre's actual thesis, and not the one mistakenly attributed to him (that Jews do not possess "Jewish traits"). To what does Misrahi attribute Sartre's inaccurate description of the Jewish condition in Europe?

According to Misrahi, who knew Sartre well both personally and professionally, Sartre's errors were not due to "obscure feelings with regard to the Jews...In truth," he insists, "his ambiguity reflected a radical opposition between Sartre's political conception of history and history's effective reality." Sartre's ambiguity is due to "both his ignorance and his Marxist convictions." 43 As Sartre's political convictions continue to solidify, his philosophical observations take shape in accordance with doctrinal demands.

Misrahi's analysis of Sartre is in line with Camus', at least with regard to Sartre's shortcomings. As Camus wrote to his future wife, Francine, regarding what he called an increasingly religious fervor in both fascism and communism, "Philosophical thought only begins when we challenge the logic of clichés with rigor and honesty." 44 For Misrahi, this is precisely what is missing from Sartre's analysis in Anti-Semite and Jew; according to Misrahi, Sartre's political commitment to Marxism prevented him from engaging in rigorous philosophical enquiry about life as it is experienced. Sartre's thinking ultimately misses the mark, in spite of his "good will," primarily because of his desire to prove Hegelian Marxist theories of history. As Camus asserted about the rebel who has forgotten the origin of his rebellion, Sartre "has taken refuge in doctrine."

Améry also finds a disconnection from the experiences of European Jews in Anti-Semite and Jew. Again, Améry explicitly praises Sartre's phenomenological acuity in his study of the anti-Semite-and even, to a significant degree Sartre's application of his theory of authenticity and inauthenticity 45 to European Jews; yet parts of Améry's At the Mind's Limits contain a strong and unmistakable undercurrent that chastises Sartre's naiveté and indicates that his politicized conceptions of reality often fail to accurately describe or even correctly address lived, human experience. This is most pronounced in the essay "On the Impossibility and Necessity of Being a Jew." Améry begins with a recollection of his first encounter with the Nuremberg Laws:

[In] 1935...I was sitting over a newspaper in a Vienna coffeehouse...studying the Nuremberg Laws, which had been enacted in Germany. I needed only to skim them [to] perceive that they applied to me. Society, concretized in the National Socialist German state, which the world recognized as the legitimate representation of the German people, had just made me formally and beyond question a Jew, or rather it had given a new dimension 
to what I had already known earlier, but which at the time was of no great consequence to me, namely, that I was a Jew. 46

After he read the Nuremberg Laws he was "no more Jewish than a half hour before... [except] that henceforth I was a quarry of Death..." 47

The image of Améry pouring over the newpaper in a Vienna coffeehouse reading his own death sentence is indescribably poignant; as Hannah Arendt asserts, his experience underscores the claim that we have no civil rights unless one is a citizen of a state that endows them upon usand moreover, will go to great lengths to protect them. "I am certain that in that year," Améry claims, "at that moment when I read the Laws, I did indeed already hear the death threat-better, the death sentence-and certainly no special sensitivity toward history was required for that." 48 With this pointed but subtle claim about the faculty of "sensitivity toward history" and its limited role in seeing what should have been obvious to every European about what would - sooner or later - be the plight of every European Jew, Améry begins his covert, impassioned dance with Sartre. Despite Sartre's "unassailable points" about the anti-Semite, Améry contends:

...in his short phenomenological sketch Sartre could not describe the total crushing force of antisemitism, a force that had brought the Jew to that point, quite aside from the fact that the great author himself [Sartre] probably did not comprehend it in its entire overwhelming might. 49

In other words, it takes no special sensitivity to or awareness of lived history to verify that the Jew had been delivered a death sentence in no uncertain terms; documentation of the Nazi view of Jews abounds. Améry goes on to affirm that, given Sartre's insufficient assessment of Jewish experience, it does take something more than the ability to understand this documentation to see clearly the Jews' lived experience. For Améry, Sartre's assertions about the "inauthentic" Jew, that is "the Jew who has fallen victim to the myth of the "universal man" - subjugates himself, in his flight from Jewish fate, to the power of his oppressor," 50 indicate a disconnection from history as it is lived. Even Sartre's extolment of the "authentic Jew" lacks genuine fidelity to human experience (who as Misrahi points out, is left with only two, very limited options for authenticity according to Sartre). Améry is right; Sartre is missing the point. "The Jew', whether he is "authentic" or "inauthentic," was forced to experience the ramifications of Jewishness. His behavior, his self-image, his political persuasion were irrelevant.

...in the years of the Third Reich the Jew stood with his back to the wall, and it too was hostile. There was no way out. Because it was not only radical Nazis...who denied that we were worthy of being loved and thereby worthy of life. All of Germany - but what am I 
saying! - the whole world nodded its head in approval of the undertaking, even if here and there with a certain superficial regret. Thus,

...it necessarily had to reach the point where Jews, whether authentic or not, whether secure in the illusion of God and a national hope, or assimilated, found within themselves no powers of resistance when their enemies burned the image from Streicher's Stürmer into their skin...this...had little to do with the classical Jewish self-hatred...to oppose [social reality] with a self-evaluation based on other standards at times had to appear ridiculous or mad. 51

Améry rejects key aspects of Sartre's phenomenology of 'the Jew and his experience' by delicately but firmly stating that to consider the matter as deeply as Sartre attempts to do, "one must have experienced it." 52 The entire essay is evocative of a dialogue between a student who quietly but resolutely rejects a fundamental claim of a beloved teacher, and certainly illustrates what Adrian West calls Améry's "almost perversely intimate relationship" with Sartre's texts. ${ }^{53}$

For Améry, as for Camus, the grave danger of reading human experience strictly through the lens of historical theory becomes most obvious regarding the question of human dignity, the question with which this essay's examination begins. Despite Améry's reluctance to define dignity in immutable terms, it is nonetheless a central theme of his work, and the foot of his philosophical compass. As part of his criticism of the limitations of Sartre's Anti-Semite and Jew, he offers a formulation of 'dignity,' something "first denied" Améry in 1935 and "officially withheld" from him until 1945. He proposes that in the final reckoning, when we find ourselves legally and forcefully denied our 'dignity,' it becomes obvious that it cannot be defined solely through the logical deduction that dignity is both destroyed and restored via social contract; when we attempt to "convince society of [our] dignity by taking [our] fate upon [ourselves] and at the same time rising in revolt against it" we may re-acquire what was taken from us. 54

At this point in Améry's analysis, he shares aspects of Camus' understanding of revolt and its relationship to human dignity and simultaneously moves away from it. Améry's experience of dignity - and his attempts to retain it in the face of brutal, repeated, and inescapable dehumanization-could not be further from Sartre's exhortations that persecuted Jews should resist "the constant temptation to consider that they are not like other men." 55 And although Sartre strongly states that, "authenticity manifests itself in revolt," 56 it is difficult to imagine that he had in mind the physical defiance that Améry recognizes as fundamental to his personhood in the camps. Améry insists regarding his struggle to regain 
dignity there is "not much that can be said in [his] favor," but that he did "finally relearn... what I and my kind often had forgotten and what was more crucial than the moral power to resist: to hit back." 57 Physical revolt is an important aspect of his claims about dignity, as is the necessity of the body in dignity's reclamation. Améry aptly relates an encounter with a kapo illustrating this:

In Auschwitz [the prison foreman] once hit me in the face for a trifle; that was how he was used to dealing with all the Jews...At this moment - I felt it with piercing clarity - it was up to me to go a step further in my prolonged appeals case against society. In open revolt I stuck Juszek in the face in turn. My human dignity lay in this punch to his jaw-and that it was in the end I, the physically much weaker man who succumbed and was thrashed meant nothing to me. Painfully beaten, I was satisfied with myself... because I had grasped well that there are situations in life in which our body is our entire self and our entire fate. I was my body and nothing else...my body, when tensed to strike was my physical and metaphysical destiny. In situations like mine, physical violence is the sole means for restoring a disjointed personality. In the punch, I was myself-and for myself and for my opponent. I gave concrete social form to my dignity by punching a human face. 58

Améry's new understanding of dignity did not change after 1945. He rejects the idea of pacifism as a viable political response to military (as Camus had done in 1943), and also the "deceptive peace" that follows the defeat of National Socialism. "I had to recognize," he avers, "even more clearly than in those days when physical revolt was at least possible that I was confronted with necessity and impossibility." 59 Finally, Améry admits, "the parentheses are now closed...I find myself in the postwar years, which no longer permitted any of us to react with violence to something that refused to reveal itself clearly to us. ${ }^{60}$

Améry's experiences as a "Catastrophe Jew" are not explained or understood by means of any single religious, philosophical, or political theory. He was frequently misunderstood by Jewish intellectuals who contested his right to call himself a Jew simply because he identified with Jewishness solely as a Nazi victim. ${ }^{61}$ He agrees that perhaps his "consciousness of being...a Holocaust Jew" may be "compared to [Marx's] class consciousness," but not entirely. He writes,

I believe to have recognized that the most extreme expectations and demands directed at us are of a physical and social nature. That such knowledge has made me unfit for profound and lofty speculation, I know. It is my hope that it has better equipped me to see reality. ${ }^{62}$ 
Améry and Camus both grew increasingly suspicious of dogmatic politics after 1945, especially its frequent deification of universalizing theories about human experiences likely to belie them. This shared suspicion was the result of personal experiences and lends their work conscientious lucidity and unabashed individualism. Améry likely despaired Sartre's inability to see that the plight of the European Jews clearly. But Sartre viewed human experience through a Hegelian lens; this affected the way he understood the world around him in profound ways. It seems unlikely that Sartre would have easily admitted that his own experiences as a white upper-class Frenchman limited his understanding of minority experience, and yet arguably, it did.

Améry's most painful betrayal did not come from Sartre, however, but from what became of the left after 1945. In his 1977 preface to At the Mind's Limits, Améry deplores the menace of historical revisionism and other forms of politically inspired forgetfulness by identifying himself as a 'rebel':

I rebel: against my past, against history, and against a present that places the incomprehensible in the cold storage of history and thus falsifies it in a revolting way. Nothing has healed, and what perhaps was already on the point of healing in 1964 is bursting open once again as an infected wound...63

Here Améry articulates the final heartbreak: that his "natural enemies" (fascists, irrationalists, reactionaries) were no longer his worst enemies. "That today," Améry writes, "I must stand up against my natural friends, the young men and women of the Left, is more than overtaxed "dialectics":

It is one of those bad farces of world history that make one doubt the sense of all historical occurrence and the end of despair...I was...not really surprised when I learned that at a rally for Palestinians in a large German city not only was "Zionism"...condemned as a global plague, but also...young antifascists made their...vigorous cry: "Death to the Jewish people." 64

When Améry laments the year 1964, he likely refers to the appearance of French Holocaust denier Paul Rassinier's 1964 book, The Drama of the European Jews. But why this particular book, written by this particular man? What is Rassinier's part in Améry's experience of betrayal?

Rassinier was a trained historian and a survivor of Buchenwald; but he also collaborated with fascists during the war at the same time that he was a committed Resistant; Rassinier identified as a hard leftist for decades, and served briefly as a socialist in the National Assembly. ${ }^{65}$ In his earliest writings, he primarily took issue with the representation of the Nazi camps in the testimonies of fellow survivors. For Rassinier, these memoirs "presented a distorted view of the phenomenon of the camps...[in that] they 
painted an unnecessarily bleak picture."66 Elhanan Yakira describes succinctly Rassinier's concerns about representations of Nazi ideology and practice:

According to Rassinier, the camps were merely another manifestation, however extreme... of the universal logic of exploitation and enslavement. Holding prisoner masses of people, who were on the verge of death while negating their dignity and humanity, was not part of a policy of destruction...but...was done according to the...logic of war...the Nazi camps were not the...expression of any particularly [uniquely] murderous philosophy...produced by the state or the enslavement or exploitation on which it depended. ${ }^{67}$

Understood in this way, the Reich's brutality fits neatly into the anticipated trajectory of history, and therefore is not an aberration but a fulfillment of certain interpretations of Hegelianism. Rassinier claims that gas chambers were not installed as tools of mass extermination of Jews and other minority groups. While he admits that there were gas chambers in some camps, he argues that their location (near what he euphemistically calls the "sanitation facilities") suggests they were not implements of mass murder, even though "some" inmates were indeed killed in them. ${ }^{68}$

"The connection between [collaborators and fascists] and Rassinier," writes Yakira, created "an alliance of radical right and radical left" regarding "the denial of the Holocaust. Thus, by a kind of perverse osmosis, the basic themes of this denial crossed the boundary separating the two political camps, creating a shared ideology: anti-Semitism, anti-Zionism, antiIsraelism, anti-Communism, and pacifism." 69 Rassinier became increasingly right wing, but not before Holocaust denial had taken hold in certain streams of leftist thought. Rassinier's pointedly titled The Drama of the European Jews, directly attacked Raul Hilberg's watershed project, The Destruction of the European Jews published in 1961. In The Drama of the European Jews, Rassinier argues that there was never a Nazi policy of extermination, a Final Solution to the "Jewish Question." He takes Hilberg to task by questioning eyewitness accounts and again contends that the primary means of extermination were not technically feasible and therefore not responsible for the number of deaths attributed to it.

What do we make of Rassinier, whose theories are all the more astounding because he is a survivor of the camps who was submersed in the "concentrationary universe"? Anti-Semitism alone, despite the madness it can impart, does not account for Rassinier's sustained efforts-he wrote twelve books, in fact-to prove, in spite of overwhelming evidence, that the genocide of European Jewry never took place. His work had an enormous impact. That he was a survivor of Buchenwald himself was damning evidence. Moreover, Rassinier was for many years a militant pacifist, and 
strains of this core value can be teased out even from The Drama of European Jews that pained Améry so deeply. Rassinier's political allegiances shifted ever further to the right, and yet his ideas remained revolutionary in the way that Camus describes in The Rebel: guided by rigidly defined doctrinal commitments, and always focused on the negation of what is for what, in the mind of the revolutionary rebel, ought to be. ${ }^{70}$

In later years, Zionism became a unique manifestation of evil for Rassinier. "Zionists from all over the world," he snarled, "...have cried unceasingly...to publicize what they consider the true and apocalyptic proportions of the horror and torture suffered from Nazism, and thereby to increase the amount of reparations which the State of Israel receives from Germany." 71 According to doctrines Rassinier embraced, injuries committed against individual members or subgroups identified as exploiters are marginal when considered with broader, revolutionary goals in mind. Yakira aptly states,

Both in Rassinier and in his followers on the radical French left, one can find this syndrome: one must not allow the crime that was committed at Auschwitz...to blind us to...the suffering of those who are truly exploited - The workers, people of the Third World, the Palestinians. What happened at Auschwitz was...just another instance among many of the true source of all crimes: colonialism, imperialism, capitalism, and Zionism. ${ }^{72}$

Such thinking arguably makes it possible to remain largely indifferent to injustices not immediately accounted for by these phenomena.

Camus also experienced a perceived betrayal from his comrades on the left that informs The Rebel and its exhortation of rebellion that forgets its own commandments regarding the value of human life. The "purification" process immediately following the defeat of the Reich proved profoundly disappointing. In August of 1945, he wrote in his Carnets, "the...process in France is already ruined, but, even worse, discredited."73 Some court decisions regarding sentencing seemed incoherent; the pacifists who collaborated with fascist groups during the war further complicated matters. The war turned Camus away from pacifism for good. He felt that "...[t]otal pacifism seems to me bad reasoning, and we now know that...it cannot [always] be upheld..."74 On the day of the German surrender, there were violent demonstrations in Algeria for its liberation from France. The French press focused almost exclusively on European casualties, but Camus wrote articles about the Algerian uprisings in Combat that attempted to shed light on the plight of Arab Algerians. Algeria is not France, Camus insisted, and years of discrimination and racism left many Algerians disillusioned about assimilation with France. "The North African natives," he wrote, "have distanced themselves from a democracy from which they see themselves as definitely excluded...they no longer wish to be French." 75 Camus' interest in 
the plight of native Algerians and his support for Algerian nationalism was complex, however. He felt strongly that Algeria should maintain ties with France, but alter completely its position toward the population of Algeria. This made him, as Olivier Todd claims, a "solitary voice" on the matter. ${ }^{76}$

In 1946, The Plague is published, and Camus distances himself further and further from both communism and existentialism. When terrorist attacks broke out in Algeria in late 1954, Camus rejected François Mitterand's declaration that "Algeria is France!" and the Front for National Liberation's declarations against colonialism, asserting that these positions reflected profound oversimplification of life in Algeria. Only a small minority of European Algerians were "captains of industry." Most were working class or manual laborers like Camus' family, and the standard of living for pieds noirs was twenty percent lower than in France. Camus knew that the majority of European Algerians did not support equal rights for Muslim Algerians. He denounced the profound racism of colonial Algerian society, and he worried about the plight of working class European Algerians should the revolution succeed. These "European" Algerians were Algerians, too. No revolutionary nationalist theory could change that. Only by addressing the plight of European Algerians in the event of a revolution-a question, too, of human rights-could the condition of all Algerians be practically addressed. "[O]bviously it's easier to be anticolonialist in the bistros of Marseilles and Paris," Camus quipped.77 Peter Beaumont acknowledges that, "for those in the pro-independence movement he would never be forgiven for one remark whenever he is discussed in an Algerian context: "At this moment bombs are being planted in the trams in Algers. My mother could be on one of those trams. If that is justice, I prefer my mother." 78 Camus' mother was nearly deaf and illiterate, and did not want to live in Paris because, she said, there were no Arabs in Paris. "The writer," Camus muses, "becomes committed when he wants to." 79

On August 28, 1947, two years after the liberation of Auschwitz, Jackie Robinson signed with the Dodgers during a secret meeting with Branch Rickey. Robinson became the first player of African descent to play professional baseball in the twentieth century. "What I'm looking for is more than a great player," Rickey told Robinson. "I am looking for a man that will take insults, take abuse - and have the guts not to fight back." For Robinson, a civil rights activist before there was a civil rights movement, even the prospect of such pacifism was a violation. His wife Rachel wrote that his first two years with the Dodgers were "the most challenging...of his career. All of his instincts cried out for release to retaliate." 80 Améry, Camus, and Robinson, all from the same generation and embroiled in political and social tragedies beyond their control, articulate the value and source of human dignity in strikingly similar ways that defy the social norm. Robinson 
described his initial response to Rickey's demand for two years of stoic silence in the face of denigration and even violence:

All my life, I had believed in payback, retaliation; the most luxurious possession, the richest treasure anybody has is his personal dignity. I had a question, and it was the age old one about whether or not to sell your birthright. Could I turn the other cheek? I didn't know how I would do it. Yet I knew that I must. ${ }^{81}$

While Améry in Brussels and Camus in Paris had through necessity come to understand human dignity in these terms, Robinson had been born to it; fighting back was in fact his "birthright." Just as Améry must face postwar Europe without "punching a human face" to assert his dignity, Robinson must make the contribution for which he is best known by denying the reality of human dignity as he understood it, instead "selling it" for the price of admission for black players who would follow him.

Robinson also experienced what for him was a political betrayal that made him, like Améry and Camus, a "solitary voice" speaking from the eye of a political storm. Robinson was an active New York Republican, which "meant supporting Nelson Rockefeller and Jacob Javitz, who supported the Civil Rights movement," instead of Southern Democrats who were almost exclusively against it.82 Robinson belonged to the party of Lincoln; he endorsed Nixon for president in 1960 after discussions with John Kennedy indicated he was noncommittal on civil rights. When Kennedy, rather than Nixon made efforts to get Martin Luther King, Jr. released from prison, Robinson "withstood intense pressure-including from his wife Rachel - to follow King's father in switching from Nixon to Kennedy..." As a result, he was denounced as an "Uncle Tom." In 1964, Robinson campaigned for Gov. Rockefeller, but Barry Goldwater was elected the party candidate. As a special delegate for Rockefeller at the Republican convention that year, an Alabama man "turned on [Robinson] menacingly when he cheered for Rockefeller aloud." The Alabaman's wife grabbed her husband's arm "and pulled him back." Robinson, free now to, in the words of Améry, "punch a human face," cried "Turn him loose, lady, turn him loose!" He voted for Johnson that year. When Nixon made overtures to racist Dixie-crat Strom Thurmond of South Carolina, he again voted Democrat. Robinson confessed to a friend in March, 1968, "I want so much to be a part of and to love this country as I once did." 83

${ }^{1}$ J ean Améry, At the Mind's Limits, trans. Sidney Rosenfeld and Stella P. Rosenfeld. (Bloomington: Indiana University Press), 28-29.

2 lbid., 86. 
${ }^{3}$ Rober Misrahi and Carol Marks, "Sartre and the J ews: A Felicitous Misunderstanding." October 87, Winter (1999): 64 .

${ }^{4}$ Ibid.

${ }^{5}$ J ean-Paul Sartre, Anti-Semite and J ew: An Exploration of the Etiology of Hate, Trans. George J. Becker. (New York: Schocken Books, 1946), 40.

${ }^{6}$ Sartre, 53.

${ }^{7}$ Sartre, 54.

${ }^{8}$ Améry, vii.

9 lbid.

${ }^{10}$ Améry, At the Mind's Limits, 31.

${ }^{11}$ Améry, viii.

${ }^{12}$ Améry, vii.

${ }^{13}$ Améry, At the Mind's Limits, $x$-xi.

14 Ibid., x-xi.

${ }^{15}$ Albert Camus, An Essay on Man in Revolt. Trans. Anthony Bower, (New York: Alfred A. Knopf, 1956),

$12-13$.

${ }^{16}$ Améry, At the Mind's Limits, 35.

17 Ibid.

${ }^{18}$ Améry, At the Mind's Limits, 36.

${ }^{19}$ Camus, 54.

${ }^{20}$ Camus, The Rebel, 56.

${ }^{21}$ Camus, 65

22 Camus, 27

${ }^{23}$ Camus, 31.

${ }^{24}$ Camus, 21-22.

${ }^{25}$ Camus, 30.

${ }^{26}$ Camus, 14-15. Camus and Améry differ here, since Améry commited suicide in 1978, two years after his treatise on suicide was completed. Améry asserted that he chose to end his own life rather than live through the inevitable decline caused by aging. Améry felt that we belong to ourselves before we belong to anyone or anything else; suicide is a birthright.

${ }^{27}$ Camus, The Rebel,, 17.

$28 \mathrm{lbid}$.

${ }^{29}$ Camus, The Rebel, 23. 
30 Olivier Todd, Albert Camus: A Life, trans. Benjamin Ivry (New York: Carroll and Graf Publishers, 2000), 181.

31 Todd, Albert Camus, , 200.

32 Todd, Albert Camus, , 201.

33 Todd, Albert Camus, , 214.

34 Todd, Albert Camus, , 215.

35 Todd, Albert Camus, , 84.

${ }^{36}$ Misrahi, 65.

${ }^{37}$ Améry, 83.

38 Sartre, 117-118.

39 Misrahi, 65.

40 Misrahi, , 66.

41 Misrahi, 66.

42 Misrahi, , 66.

43 Misrahi, , 68.

44 Todd, 92.

45 See Sartre's Being and Nothingness.

${ }^{46}$ Améry, 85.

${ }^{47}$ Améry, 85.

${ }^{48}$ Améry, 85.

${ }^{49}$ Améry, 86.

50 Ibid.

${ }^{51}$ Améry, At the Mind's Limits, , 86-87.

${ }^{52}$ Améry, At the Mind's Limits, , 87.

53 Adrian West, "Hope as Insult and Provocation: On Jean Améry's Suicide," Asymptote Journal, 2016. Found on line: http://www.asymptotejournal.com/ special-feature/ adrian-west-on-jeanamery/

Last accessed Sept 3, 2017. See also the link to West's translations of Améry's suicide notes into English, along with a recording of the notes in the original German by Leopold Lippert: http:// www. asymptotejournal.com/nonfiction/ jean-amery-suicide-notes/

${ }^{54}$ Améry, 89.

55 Sartre, 101.

56 Sartre, , 108.

57 Améry, 90. 
${ }^{58}$ Améry, 90-91.

${ }^{59}$ Améry, , 92.

60 Améry, 93.

${ }^{61}$ Sidney Rosenfeld, "Afterword," At The Mind's Limits, 109.

62 Améry, 101.

${ }^{63}$ Améry, , xi.

${ }^{64}$ Améry, , $x$.

65 Yakira, 8. See Olivier Todd's biography of Camus, cited in this essay, for more on Sartre and Beauvoir's support for capital punishment for collaborators. Also, for more on Brasillach, see Zeev Sternhell, Neither Right Nor Left: Fascist Ideology in France (Princeton University Press, 1996).

66 Elhanan Yakira, Post-Zionism, Post Holocaust: Three Essays on Denial, Forgetting, and the Delegitamation of Israel, trans. Michael Zwirsky, (Cambridge: Cambridge University Press, 2010),

6.

67 Yakira, , 6-7.

${ }^{68}$ Rassinier, found in Yakira, 8.

${ }^{69}$ Rassinier, found in Yakira,, 9.

70 The role that pacifism played in early to mid-twentieth century France cannot be underestimated, and deserves a treatment that is beyond the scope of this project. In Rassinier's lifetime, pacifism was associated with the left, but did not necessarily include commitments to communism or socialism. One of the most interesting forms of pacifism is called "Alainist" pacifism, held by many young intellectuals of the time. Alain, or Émile-Auguste Chartier, was a well-known professor and gifted teacher at the École Normale Supérieure in Paris, a prep school for aspiring government officials and academics. Among former students influenced by Alain were Sartre, Maurice Merleau-Ponty, Raymond Aron, Simone Weil, and Claude Levi-Strauss. Alain did not present a systematic theory of pacifism, but made uncompromising indictments of war that relied on emotional impact. Alain's disciples enacted their pacifist principles in different ways. Some became members of the resistance and others actively collaborated with the Germans and the Vichy regime. Some Alainists viewed war as the ultimate evil; only moral and political bankruptcy could lead us to believe that it is truly unavoidable. Rassinier's anarchist pacifist roots are a product of the time. Probably, Améry and Camus finally reject pacifism not only based on personal conviction, but also because they saw first hand the ramifications of pacifism in the face of nihilistic fascism. For more on this, see $E$. Yakira's Post-Zionism, Post-Holocaust: Three Essays on Denialm Forgetting, and the Delegitimation of Israel (Cambridge University Press: Cambridge, 2010) and Alain Finkielkraut's The Future of a Negation: Reflections of the Question of Genocide, trans. Mary Byrd Kelly (University of Nebraska Press: Lincoln, 1998).

71 Paul Rassinier, The Real Eichmann Trial, or The Incorrigible Victors. (Silver Spring, Md.: Steppingstones, 1979; Ladbroke, Southam, Warwickshire: Historical Review Pres, 1979), 47.

72 Yakira, 21. 
73 Todd, 202.

74 Ibid.

75 Todd, , 203.

76 Todd, , 204.

77 Todd, , 325.

78 Peter Beaumont, "Albert Camus, the outsider, is still dividing opinion in Algeria 50 years after his death," The Guardian. Saturday, Feb 27, 2010. Last accessed on September 5, 2017. https:// www.thequardian.com/ books/ 2010/ feb/28/ albert-camus-al geria-anniversary-row

79 Todd, 237.

80 From Rachel Robinson's book, Jackie Robinson: An Intimate Portrait. Found in George Willis' "A Man for All Reasons," New York Post, Nov 7, 1999. Last accessed on Sept 4, 2017: http:/ / nypost.com/ 1999/ 11/ 07/ a-man-for-all-reasons/

${ }^{81}$ Ken Burns director, J ackie Robinson. Part 1.

82 Scott Simon, Jackie Robinson and the Integration of Baseball (J ohn Wiley and Sons: Hoboken, NJ 2002), 159.

83 Michael Beschloss, "J ackie Robinson and Nixon: Life and Death of a Political Friendship," The New York Times. June 6, 2014. Last accessed on September 5, 2017. http:// www. nytimes. com/ 2014/ 06/ 07/ upshot/ jackie-robinson-and-nixon-life-and-death-of-apolitical-friendship.html? $r=0$ 